\title{
Lishizhenia tianjinensis sp. nov., isolated from coastal seawater
}

\author{
Li-Ping Chen, † Hai-Ying Xu, † Song-Zhe Fu, Hong-Xia Fan, \\ Yu-Guang Zhou and Zhi-Pei Liu
}

Correspondence
Zhi-Pei Liu
liuzhp@sun.im.ac.cn

The genus Lishizhenia was established by Lau et al. (2006). At the time of writing, the genus comprises one recognized species, Lishizhenia caseinilytica (Lau et al., 2006). The genus Lishizhenia is a member of the family Cryomorphaceae (Bowman et al., 2003) in the class Flavobacteria (designation according to Cavalier-Smith, 2002) of the phylum Bacteroidetes. Members of the Cryomorphaceae are psychrotolerant, rod-shaped to filamentous and possess carotenoid pigments. They also require seawater salts and complex organic compounds for growth and are unable to utilize carbohydrates (Bowman et al., 2003; Lau et al., 2005; O'Sullivan et al., 2005). Molecular phylogenetic studies have found that phylotypes related to the Cryomorphaceae are associated with phytoplankton blooms (Pinhassi et al., 2004; Grossart et al., 2005). In a study of the bacterial diversity in Tianjin coastal seawater, a non-carbohydrate-utilizing, mesophilic, orange-pigmented, rod-shaped, moderately halophilic bacterium, strain $\mathrm{H}^{\mathrm{T}}$, was isolated and subsequently characterized by use of a polyphasic taxonomic study. On the

†These authors contributed equally to this paper.

The GenBank/EMBL/DDBJ accession number for the $16 \mathrm{~S}$ rRNA gene sequence of strain $\mathrm{H}^{\top}$ is EU183317.

A scanning electron micrograph of cells of strain $\mathrm{H}^{\top}$ and cellular fatty acid profiles of strain $\mathrm{H}^{\top}$ and Lishizhenia caseinilytica $\mathrm{JCM} 13821^{\top}$ are available as supplementary material with the online version of this paper. basis of the phenotypic, chemotaxonomic and phylogenetic data presented herein, strain $\mathrm{H}^{\mathrm{T}}$ is considered to represent a novel species of the genus Lishizhenia.

A coastal seawater sample was collected from Tianjin, China. The sample was diluted 10 -fold with sterilized $2 \%$ $\mathrm{NaCl}(\mathrm{w} / \mathrm{v})$ solution, spread on low-organic seawater medium (LOSWM; containing $1.0 \mathrm{~g}$ peptone, $0.50 \mathrm{~g}$ yeast extract and $15 \mathrm{~g}$ agar per litre of seawater) and was incubated at $30{ }^{\circ} \mathrm{C}$ for 10 days. Individual colonies were picked, cultured in LOSWM and stored at $-20{ }^{\circ} \mathrm{C}$ in $20 \%$ $(\mathrm{v} / \mathrm{v})$ glycerol. Strain $\mathrm{H}^{\mathrm{T}}$ was obtained after several streakings and transfers on LOSWM plates; the organism was also able to grow in marine broth 2216 (MB; Difco) and on marine agar 2216 (MA; Difco).

Routine cultivation was conducted at $30{ }^{\circ} \mathrm{C}$ on MA. Cell morphology was examined by transmission electron microscopy (H600; Hitachi) and scanning electron microscopy (200; FEI Quanta). Gliding motility was investigated as described by Bowman (2000). The Gram reaction was determined by staining cells grown on $\mathrm{MA}$ at $30{ }^{\circ} \mathrm{C}$ for $24 \mathrm{~h}$ according to the method described by Gerhardt et al. (1994). Endospore formation was determined after malachite green staining (Dong \& Cai, 2001) of cells grown on MA. Cells of strain $\mathrm{H}^{\mathrm{T}}{ }^{\mathrm{w}}$ were Gram-negative, non-sporeforming, non-flagellated, motile, flexible rods, $0.3-0.4 \mu \mathrm{m}$ wide and 1.5-3.5 $\mu \mathrm{m}$ long (see Supplementary Fig. S1 in IJSEM Online). 
The $\mathrm{pH}$ range for growth was determined in $\mathrm{MB}$ that was adjusted to various $\mathrm{pH}$ values (initial $\mathrm{pH} 7.0-10$, at intervals of $0.2 \mathrm{pH}$ units) with $\mathrm{HCl}$ or $\mathrm{Na}_{2} \mathrm{CO}_{3}$. Growth at various temperatures $\left(0-40{ }^{\circ} \mathrm{C}\right)$ was measured on MA. The requirement for sodium ions and tolerance of $\mathrm{NaCl}$ were determined in $\mathrm{MB}$ with $\mathrm{NaCl}$ concentrations of 0 $7.0 \%(\mathrm{w} / \mathrm{v}$, intervals of $0.5 \% \mathrm{NaCl})$. Anaerobic growth was determined in $\mathrm{MB}$ in anaerobic test tubes with nitrogen gas. Catalase activity was determined based on the formation of bubbles after a $3 \% \mathrm{H}_{2} \mathrm{O}_{2}$ solution was dropped onto a fresh colony. Oxidase activity and hydrolysis of casein, starch and Tweens 20, 40, 60 and 80 were determined as described by Dong \& Cai (2001) but using artificial seawater (ASW) instead of distilled water. The ASW contained (per litre distilled water) $23.6 \mathrm{~g} \mathrm{NaCl}$, $0.64 \mathrm{~g} \mathrm{KCl}, 4.53 \mathrm{~g} \mathrm{MgCl}_{2} .6 \mathrm{H}_{2} \mathrm{O}, 5.94 \mathrm{~g} \mathrm{MgSO}_{4} .7 \mathrm{H}_{2} \mathrm{O}$ and $1.3 \mathrm{~g} \mathrm{CaCl}_{2} \cdot 2 \mathrm{H}_{2} \mathrm{O}$ (Bruns et al., 2001). Acid production from carbohydrates was determined by using API $50 \mathrm{CH}$ strips (bioMérieux), with a medium comprising $50 \%$ $\mathrm{CHB} / \mathrm{E}$ medium (bioMérieux) with $0.075 \% \mathrm{CaCl}_{2} \cdot 2 \mathrm{H}_{2} \mathrm{O}$, $1.875 \% \mathrm{NaCl}$ and $0.375 \% \mathrm{MgCl}_{2}$. Carbohydrate assimilation was determined by using API $50 \mathrm{CH}$ strips, with ASW supplemented with $0.05 \%$ yeast extract for resuspension of cells, and the strips were incubated at $30{ }^{\circ} \mathrm{C}$ for 2 weeks. Additional biochemical tests were performed by using the API 20NE and API ZYM galleries (bioMérieux). The above tests were performed according to the manufacturer's instructions. Susceptibility to antibiotics was determined on MA plates by using filter-paper discs (Beijing Pharmaceutical Company) containing various antibiotics as specified in the species description. The phenotypic properties of strain $\mathrm{H}^{\mathrm{T}}$ are given in Table 1 and in the species description.

The absorption spectrum was examined by spectroscopy. Strain $\mathrm{H}^{\mathrm{T}}$ was grown in MB. Cells were harvested, resuspended in absolute ethanol and sonicated for $10 \mathrm{~s}$. The sonicated cell material was then filtered through a 0.2- $\mu \mathrm{m}$ Whatman filter and the absorption spectrum between 300 and $700 \mathrm{~nm}$ was determined with a UNICO UV$2802 \mathrm{H}$ spectrophotometer (Shanghai Optical Company). The bathochromatic shift test for flexirubin was performed by addition of $20 \% \mathrm{KOH}$ (Fautz \& Reichenbach, 1980). Strain $\mathrm{H}^{\mathrm{T}}$ contained carotenoid pigments with major absorption peaks at 445, 471 and $503 \mathrm{~nm}$, as found for $L$. caseinilytica JCM $13821^{\mathrm{T}}$ (Lau et al., 2006).

The cellular fatty acid profile of strain $\mathrm{H}^{\mathrm{T}}$ was determined via the MIDI Sherlock Microbial Identification System (Microbial ID) with cells grown on MA at $30{ }^{\circ} \mathrm{C}$ for 3 days. Isoprenoid quinone analysis was performed by the HPLC method (Collins, 1994), with menaquinones extracted from L. caseinilytica JCM $13821^{\mathrm{T}}$ (Lau et al., 2006) as reference. Strain $\mathrm{H}^{\mathrm{T}}{ }^{\mathrm{C}}$ contained iso- $\mathrm{C}_{15: 0}(36.5 \%$ of the total), iso- $\mathrm{C}_{15: 1}(27.3 \%)$ and iso- $\mathrm{C}_{17: 0} 3-\mathrm{OH}(10.8 \%)$ as major fatty acids, a similar profile to that of $L$. caseinilytica JCM $13821^{\mathrm{T}}$. Strain $\mathrm{H}^{\mathrm{T}}$ differed from $L$. caseinilytica JCM $13821^{\mathrm{T}}$ in that $\mathrm{C}_{15: 0}, \mathrm{C}_{15: 0} 2-\mathrm{OH}$ and $\mathrm{C}_{16: 0} 2-\mathrm{OH}$ were present at low levels $(1.1-2.1 \%)$, while $\mathrm{C}_{16: 0} 3-\mathrm{OH}$ was not detected (Supplementary Table S1). The sole respiratory quinone was menaquinone-6 (MK-6).

The $\mathrm{G}+\mathrm{C}$ content of the genomic DNA was determined by thermal denaturation (Marmur \& Doty, 1962) with DNA from Escherichia coli K-12 as a standard for calibration of the $T_{\mathrm{m}}$ value. The $\mathrm{G}+\mathrm{C}$ content of strain $\mathrm{H}^{\mathrm{T}}$ was $34.6 \mathrm{~mol} \%$.

The 16S rRNA gene of strain $\mathrm{H}^{\mathrm{T}}$ was amplified by using two bacterial universal primers, $27 \mathrm{~F}$ and 1492R (Lane, 1991), and was sequenced as described by Zhang et al. (2003). Searches for similar sequences were made via the BLAST program (Altschul et al., 1990) on the NCBI database. Strain $\mathrm{H}^{\mathrm{T}}$ showed $97.8 \%$ 16S rRNA gene sequence similarity to L. caseinilytica JCM $13821^{\mathrm{T}}$, but less than $93 \%$ similarity to other members of the family Cryomorphaceae. A phylogenetic tree of $16 \mathrm{~S}$ rRNA gene

Table 1. Differential characteristics between strain $\mathrm{H} 6^{\top}$ and the type strain of Lishizhenia caseinilytica

Strains: $1, \mathrm{H}^{\mathrm{T}} ; 2$, L. caseinilytica JCM $13821^{\mathrm{T}}$ (data from Lau et al., 2006). The two strains were positive for motility, requirement of sodium ions for growth, oxidase activity and hydrolysis of gelatin and Tween 20 and negative for utilization of and acid production from carbohydrates, nitrate reduction, indole production, activity of $\alpha$-chymotrypsin, $\alpha$-galactosidase and arginine dihydrolase, and hydrolysis of starch and agar. +, Positive; -, negative; w, weakly positive.

\begin{tabular}{|lcc|}
\hline Characteristic & $\mathbf{1}$ & $\mathbf{2}$ \\
\hline Enzyme activity & - & + \\
$\quad$ Catalase & + & - \\
Esterase (C4), esterase lipase (C8), leucine arylamidase, valine arylamidase, cystine & \\
$\quad$ arylamidase, trypsin, acid phosphatase, $\beta$-galactosidase, $N$-acetyl- $\beta$-glucosaminidase & & - \\
Naphthol-AS-BI-phosphohydrolase & W & + \\
Hydrolysis of: & - & - \\
Casein & + & - \\
Tweens 40,60 and 80 & + & $35.8 \pm 0.5$ \\
Production of $\mathrm{H}_{2} \mathrm{~S}$ & 34.6 & \\
DNA G+C content $(\mathrm{mol} \%)$ & & \\
\hline
\end{tabular}


sequences was constructed by the neighbour-joining method (Saitou \& Nei, 1987) with MEGA version 3.1 (Kumar et al., 2004). Strain $\mathrm{H}^{\mathrm{T}}$ formed a distinct phylogenetic lineage within the genus Lishizhenia (Fig. 1).

Differential characteristics between strain $\mathrm{H}^{\mathrm{T}}$ and $L$. caseinilytica JCM $13821^{\mathrm{T}}$ are given in Table 1. Strain $\mathrm{E}^{\mathrm{T}}$ could be differentiated on the basis of several phenotypic features, including activity of some enzymes, hydrolysis of casein and Tweens 40, 60 and 80 and production of $\mathrm{H}_{2} \mathrm{~S}$. In order further to distinguish strain $\mathrm{H}^{\mathrm{T}}$ from L. caseinilytica JCM $13821^{\mathrm{T}}$, DNA-DNA hybridization was carried out by the thermal denaturation and renaturation method (De Ley et al., 1970) as modified by Huß et al. (1983). The level of DNA-DNA relatedness between strain $\mathrm{H}^{\mathrm{T}}$ and $L$. caseinilytica JCM $13821^{\mathrm{T}}$ was $47.4 \%$.

On the basis of phenotypic, chemotaxonomic, genomic and phylogenetic characteristics, we suggest that strain $\mathrm{H}^{\mathrm{T}}$ represents a novel species of the genus Lishizhenia, for which the name Lishizhenia tianjinensis sp. nov. is proposed.

\section{Description of Lishizhenia tianjinensis sp. nov.}

Lishizhenia tianjinensis (tian.ji.nen'sis. N.L. fem. adj. tianjinensis pertaining to Tianjin, from where the type strain was isolated).

Strictly aerobic and heterotrophic. Cells are Gram-negative, non-spore-forming, non-flagellated, motile, flexible rods, $0.3-0.4 \mu \mathrm{m}$ wide and $1.5-3.5 \mu \mathrm{m}$ long. Colonies are 1$2 \mathrm{~mm}$ in diameter, orange-pigmented, smooth and with a mucoid consistency after cultivation on MA at $30{ }^{\circ} \mathrm{C}$ for $24 \mathrm{~h}$. Growth is observed in the presence of $0.5-6.5 \% \mathrm{NaCl}$ $(\mathrm{w} / \mathrm{v})$, at $4-36{ }^{\circ} \mathrm{C}$ and at $\mathrm{pH} 7.2-9.6$, with optimum growth in $2 \% \mathrm{NaCl}$, at $30{ }^{\circ} \mathrm{C}$ and at $\mathrm{pH}$ 7.6. In the API ZYM system, shows activity for esterase (C4), esterase lipase (C8), leucine arylamidase, valine arylamidase, cystine arylamidase, trypsin, acid phosphatase, naphthol-AS-BIphosphohydrolase, $\beta$-galactosidase and $N$-acetyl- $\beta$-glucosaminidase, but not for alkaline phosphatase, $\alpha$-galactosidase, lipase (C14), $\alpha$-chymotrypsin, $\beta$-glucuronidase, $\alpha$ glucosidase, $\beta$-glucosidase, $\alpha$-mannosidase or $\beta$-fucosidase. Resistant to ( $\mu \mathrm{g}$ per disc) streptomycin (10) and neomycin

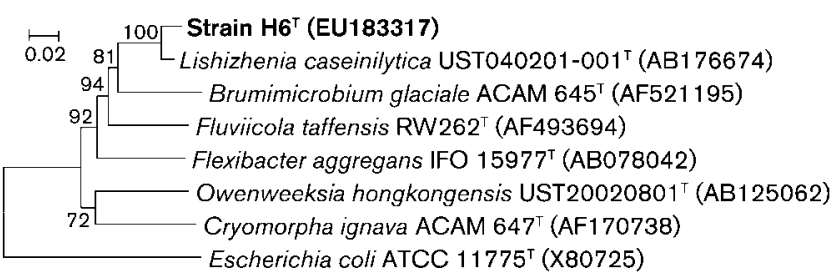

Fig. 1. Neighbour-joining phylogenetic tree based on $16 \mathrm{~S}$ rRNA gene sequence analysis showing the position of strain $\mathrm{H}^{\top}$ and related species. Numbers at nodes represent percentage bootstrap support based on an analysis of 1000 resampled datasets. Bar, $2 \%$ sequence divergence.
(30), but sensitive to benzylpenicillin (10), norfloxacin (10) carbenicillin (100), polymyxin B (300), ampicillin (10), vancomycin (30), ciprofloxacin (5), rifampicin (5), chloramphenicol (30), kanamycin (30), erythromycin (15), tetracycline (30), gentamicin (10) and novobiocin (5). Cells possess carotenoid pigments. The sole respiratory quinone is MK-6. Major fatty acids are iso- $C_{15: 0}$, iso- $C_{15: 1}$ and iso- $\mathrm{C}_{17: 0} 3-\mathrm{OH}$. The DNA G $+\mathrm{C}$ content of the type strain is $34.6 \mathrm{~mol} \%$. Additional characteristics are given in Table 1.

The type strain, $\mathrm{H}^{\mathrm{T}}\left(=\mathrm{CGMCC} 1.7005^{\mathrm{T}}=\mathrm{JCM} 15141^{\mathrm{T}}\right)$, was isolated from coastal seawater of Tianjin, China.

\section{Acknowledgements}

We thank Dr K. W. Lau at Hong Kong University of Science and Technology for provision of L. caseinilytica JCM $13821^{\mathrm{T}}$. This work was supported by the Hi-Tech Research and Development Program of China ('863' program, no. 2006AA100305).

\section{References}

Altschul, S. F., Gish, W., Miller, W., Myers, E. W. \& Lipman, D. J. (1990). Basic local alignment search tool. J Mol Biol 215, 403-410.

Bowman, J. P. (2000). Description of Cellulophaga algicola sp. nov., isolated from the surface of Antarctic algae, and reclassification of Cytophaga uliginosa (ZoBell and Upham 1944) Reichenbach 1989 as Cellulophaga uliginosa com. nov. Int J Syst Evol Microbiol 50, 1861-1868.

Bowman, J. P., Nichols, C. M. \& Gibson, J. A. (2003). Algoriphagus ratkowskyi gen. nov., sp. nov., Brumimicrobium glaciale gen. nov., sp. nov., Cryomorpha ignava gen. nov., sp. nov. and Crocinitomix catalasitica gen. nov., sp. nov., novel flavobacteria isolated from various polar habitats. Int J Syst Evol Microbiol 53, 1343-1355.

Bruns, A., Rohde, M. \& Berthe-Corti, L. (2001). Muricauda ruestringensis gen. nov., sp. nov., a facultatively anaerobic, appendaged bacterium from German North Sea intertidal sediment. Int J Syst Evol Microbiol 51, 1997-2006.

Cavalier-Smith, T. (2002). The neomuran origin of archaebacteria, the negibacterial root of the universal tree and bacterial megaclassification. Int J Syst Evol Microbiol 52, 7-76.

Collins, M. D. (1994). Isoprenoid quinones. In Chemical Methods in Prokaryotic Systematics, pp. 265-309. Edited by M. Goodfellow \& A. G. O'Donnell. Chichester: Wiley.

De Ley, J., Cattoir, H. \& Reynaerts, A. (1970). The quantitative measurement of DNA hybridization from renaturation rates. Eur $J$ Biochem 12, 133-142.

Dong, X.-Z. \& Cai, M.-Y. (editors) (2001). Determination of biochemical properties. In Manual for the Systematic Identification of General Bacteria, pp. 370-398. Beijing: Science Press (in Chinese).

Fautz, E. \& Reichenbach, H. (1980). A simple test for flexirubin-type pigments. FEMS Microbiol Lett 8, 87-91.

Gerhardt, P., Murray, R. G. E., Wood, W. A. \& Krieg, N. R. (editors) (1994). Methods for General and Molecular Bacteriology. Washington, DC: American Society for Microbiology.

Grossart, H. P., Levold, F., Allgaier, M., Simon, M. \& Brinkhoff, T. (2005). Marine diatom species harbour distinct bacterial communities. Environ Microbiol 7, 860-873. 
Huß, V. A. R., Festl, H. \& Schleifer, K. H. (1983). Studies on the spectrophotometric determination of DNA hybridization from renaturation rates. Syst Appl Microbiol 4, 184-192.

Kumar, S., Tamura, K. \& Nei, M. (2004). MEGA3: integrated software for molecular evolutionary genetics analysis and sequence alignment. Brief Bioinform 5, 150-163.

Lane, D. J. (1991). 16S/23S rRNA sequencing. In Nucleic Acid Techniques in Bacterial Systematics, pp. 115-175. Edited by E. Stackebrandt \& M. Goodfellow. Chichester: Wiley.

Lau, K. W., Ng, C. Y., Ren, J., Lau, S. C., Qian, P. Y., Wong, P. K., Lau, T. C. \& Wu, M. (2005). Owenweeksia hongkongensis gen. nov., sp. nov., a novel marine bacterium of the phylum 'Bacteroidetes'. Int J Syst Evol Microbiol 55, 1051-1057.

Lau, K. W., Ren, J., Wai, N. L., Qian, P.-Y., Wong, P.-K. \& Wu, M. (2006). Lishizhenia caseinilytica gen. nov., sp. nov., a marine bacterium of the phylum Bacteroidetes. Int J Syst Evol Microbiol 56, 2317-2322.
Marmur, J. \& Doty, P. (1962). Determination of the base composition of deoxyribonucleic acid from thermal denaturation temperature. J Mol Biol 5, 109-118.

O’Sullivan, L. A., Rinna, J., Humphreys, G., Weightman, A. J. \& Fry, J. C. (2005). Fluviicola taffensis gen. nov., sp. nov., a novel freshwater bacterium of the family Cryomorphaceae in the phylum 'Bacteroidetes'. Int J Syst Evol Microbiol 55, 2189-2194.

Pinhassi, J., Sala, M. M., Havskum, H., Peters, F., Guadayol, O., Malits, A. \& Marrase, C. (2004). Changes in bacterioplankton composition under different phytoplankton regimens. Appl Environ Microbiol 70, 6753-6766.

Saitou, N. \& Nei, M. (1987). The neighbor-joining method: a new method for reconstructing phylogenetic trees. Mol Biol Evol 4, 406-425.

Zhang, D., Yang, H., Zhang, W., Huang, Z. \& Liu, S.-J. (2003). Rhodocista pekingensis sp. nov., a cyst-forming phototrophic bacterium from a municipal wastewater treatment plant. Int J Syst Evol Microbiol 53, 1111-1114. 